\title{
INOVASI DAN PENGEMBANGAN PRODUK UKM HANDIKRAF UNTUK PASAR PARIWISATA DI BALI
}

\author{
Yusri Abdillah \\ Program Studi Pariwisata, Jurusan Administrasi Bisnis FIA UB \\ Email:YusriAbdillah@ub.ac.id
}

\begin{abstract}
Tourism is a sector that has a comprehensive multiplayer effect and provide opportunities for a variety of industries to develop through service to the needs of tourists. This study discusses the role of tourism to the development of the handicraft industry as a supplier of souvenir at the tourist market. More specifically the study was conducted to examine the process of innovation in product development of small businesses producing crafts in Malang which sells its products to market tourism in Bali. The results showed that innovation in product development and behavior is dominated by the design desired by intermediaries compared to designs offered by the company. This indicates that the intermediaries had more accurate information about the preferences of the market compared with craft souvenir producers. Thus, the manufacturers producing handicrafts for souvenirs is more to position themselves as "peasant" in order to ensure the economic viability of production and yet have sufficient orientation towards market developments directly.
\end{abstract}

Keywords: Tourism, Innovation, Marketing, souvenir industry, SMEs, Bali.

\begin{abstract}
ABSTRAK
Pariwisata merupakan sektor yang memiliki multiplayer effect luas dan memberikan peluang bagi berbagai industri untuk berkembang melalui pelayanan terhadap kebutuhan wisatawan. Studi ini membahas tentang peranan pariwisata terhadap perkembangan industri kerajinan sebagai pemasok suvenir pada pasar pariwisata. Secara lebih khusus studi dilakukan untuk menelaah proses inovasi dalam pengembangan produk usaha kecil penghasil kerajinan di Kota Malang yang menjual produk-produknya untuk pasar pariwisata di Bali. Hasil penelitian menunjukkan bahwa inovasi dan perilaku dalam mengembangkan produk lebih didominasi oleh desain yang diinginkan oleh intermediaries dibandingkan dengan desain yang ditawarkan oleh perusahaan. Hal ini mengindikasikan bahwa intermediaries memiliki informasi yang lebih akurat mengenai preferensi pasar dibandingkan dengan produsen suvenir kerajinan. Dengan demikian, para produsen penghasil kerajinan untuk suvenir ini lebih memposisikan diri sebagai "petani penghasil" guna memastikan kelangsungan ekonomi produksinya dan belum memiliki orientasi yang cukup terhadap perkembangan pasar secara langsung.
\end{abstract}

Kata Kunci: Pariwisata, Inovasi, Pemasaran, Industri suvenir, UKM, Bali. 


\section{PENDAHULUAN}

Perkembangan sektor pariwisata dalam tiga dasawarsa terakhir telah berdampak pada meningkatnya permintaan pada produk-produk seni lokal baik yang bersifat tangible maupun intangible sebagai suvenir dan pengalaman bagi wisatawan yang mengunjungi sebuah destinasi. Meningkatnya permintaan ini seringkali membawa perubahan tatanan perekonomian pada daerah tujuan wisata. Tidak jarang bahwa produk-produk budaya lokal yang sebelumnya dibuat untuk memenuhi kebutuhan upacara-upacara keagamaan, saat ini telah dimodifikasi dan beralih fungsi sebagai produk untuk melayani pasar pariwisata. Hal seperti ini tampak sangat jelas di destinasi pariwisata seperti Bali dan daerah-daerah tujuan wisata baru lainnya.

Melalui sentuhan dengan dunia pariwisata, produk-produk budaya lokal berkembang lebih pesat secara sekuler dengan inovasi-inovasi kreatif untuk memenuhi kepuasan pasar wisatawan. Inovasi ini diperlukan untuk menyesuaikan produk lokal yang dibuat dengan persepsi wisatawan tentang daerah yang dikunjunginya. Pada tahapan awal perkembangan ini, berbagai resistensi dari masyarakat lokal akan bermunculan karena produkproduk baru yang ditawarkan kepada para wisatawan dianggap mencemari budaya lokal. Namun demikian, dengan semakin berkembangnya ekonomi dan teknologi pada sebuah masyarakat maka inovasi-inovasi terhadap berbagai produk budaya beserta pemanfaatannya secara modern akan semakin dapat diterima oleh masyarakat tersebut.

Tidak berbeda dengan siklus produk yang sangat dipengaruhi oleh perkembangan teknologi, seperti (r)evolusi pita audio video menjadi cd-dvd sampai dengan diperkenalkannya blue ray disc pada saat ini, produk-produk seni dan budaya juga berkembang, tumbuh dan mati secara cepat akibat pengaruh teknologi. Sebagai gambaran, sampai dengan tiga puluh tahun yang lalu pagelaran wayang kulit di Bali masih banyak menggunaan perangkat-perangkat tradisional yang selanjutnya berkembang dengan menggunakan perangkat sound system yang lebih canggih. Saat ini pagelaran wayang kulit telah banyak melibatkan berbagai teknologi digital dan aplikasi komputer untuk menghasilkan tayangan yang lebih spektakuler. Demikian halnya dengan produk-produk budaya di Bali yang bersifat tangible seperti ukiran yang telah banyak beralih ke produksi handicraf sederhana dan bersifat massal. Produk kerajinan dan handicraf ini secara terus menerus melalui siklus hidup yang semakin pendek sebagai akibat dari cepatnya perubahan selera konsumen.

Gambaran di atas menunjukkan adanya siklus kehidupan dan kematian yang terjadi secara terus menerus di pasar-produk di seluruh dunia (Jaworski et. al, 2000). Inovasi-inovasi yang berkelanjutan seperti ini membuktikan bahwa produk, pasar, dan persaingan berubah tanpa henti. Kondisi pasarproduk yang seperti ini akan terus berlanjut, yang setidaknya terdapat tiga hal mendasar yang menjadi penyebabnya yaitu (1) Sifat kebutuhan manusia yang tidak terbatas mendorong terciptanya produkproduk baru yang inovatif melalui penerapan teknologi. (2) Struktur pasar yang telah beralih pada pasar yang dikuasai pembeli menyebabkan perusahaan harus menyesuaikan kebutuhan dan keinginan konsumen. (3) Persaingan yang datang dari perusahaan-perusahaan pesaing untuk produk sejenis maupun produsen barang substitusi.

\section{LATAR BELAKANG TEORI DAN HIPOTESIS \\ Pengumpulan dan Analisis Data}

Sebagaimana telah dikemukakan pada bagian sebelumnya tentang cara pengamatan yang dilakukan melalui observasi secara langsung pada UKM-UKM yang ditelaah, peneliti akan mengumpulan data penelitian dengan melakukan interview baik secara terbuka maupun secara semi struktur terhadap pemilik dan pelaksana produksi UKM. Dalam hal terdapat kemungkinan, para perantara bisnis akan diwawancarai untuk mendapatkan perspektif yang berbeda tentang proses inovasi pada UKM yang diamati. Disamping wawancara dengan pihak yang terkait langsung dengan proses inovasi pengembangan produk, wawancara juga dilakukan dengan pihak lain yang tidak terlibat langsung dalam proses inovasi, tetapi memiliki pemahaman tentang perkembangan usaha-usaha kecil di Kota Malang, yakni responden-responden dari Dinas Perindustrian dan Kadin Kota Malang.

Dalam penelitian ini, peneliti akan berperan sebagai observer melalui pengamatan langsung non partisipan. Peneliti akan melakukan pengamatan tentang bagaimana proses inovasi dalam pengembangan produk ini berlangsung pada usaha kecil yang sedang diamati. Proses ini mencakup bagaimana ide-ide inovatif dibangkitkan, dianalisis kelayakan pasarnya, diorganisasi, dan selanjutnya dieksekusi. Dalam observasi ini juga akan diamati seberapa besar peran dan intervensi dari pihak luar dalam proses inovasi di UKM yang sedang diamati.

Teknik obervasi non partisipan memiliki sisi keunggulan dalam penelitian ini untuk melihat proses inovasi yang berlangsung pada kegiatan pengembangan produk dari perspektif internal organisasi. Disisi yang lain interaksi dengan pihak di luar struktur UKM akan memberikan gambaran dari pihak eksternal yang memiliki kepantingan 
untuk mengembangkan UKM tentang bagaimana seharusnya proses inovasi berlangsung.

Teknik wawancara dilakukan secara terbuka dan semi terstruktur. Wawancara secara terbuka (open-ended) akan memastikan bahwa responden akan menyampaikan segala sesuatunya dari perspektif mereka tanpa ada batasan-batasan terhadap penjelasan yang mereka sampaikan. Pada bagian yang lain wawancara semi struktur akan diaplikasikan untuk menggiring responden berbicara sesuai dengan koridor penelitian yang telah ditentukan.

Penelitian ini didesain dengan menggunakan pendekatan kualitatif sedemikian semua tahapan dalam penelitian merupakan bagian dari langkahlangkah analisis terhadap data yang dikumpulkan. Analisis terhadap data juga telah dilaksanakan pada saat pra studi lapangan (Alwasilah, 2002). Keseluruah data primer yang didapatkan dalam penelitian ini adalah berupa catatan-catatan saat observasi, catatan-catatan saat melakukan wawancara, dan transripsi teks hasil wawancara yang direkam dengan menggunakan media digital. Secara simultan, analisis data dilakukan terhadap data yang dikumpulkan bersamaan dengan analisis terhadap literatur-literatur yang relevan. Dengan demikian, data dihimpun dan direkonstruksi untuk menghasilkan makna dan menghasilkan teori-teori terkait dengan objek yang sedang diteliti.

\section{Inovasi}

Dalam konteks ini inovasi dipandang sebagai kemampuan yang dimiliki oleh usaha kecil dan menengah untuk beradaptasi dengan perubahanperubahan lingkungan, termasuk dalam hal ini adalah, salah satunya, lingkungan pasar periwisata tempat ia mengoperasikan bisnisnya (Gallouj \& Windrum, 2009). Pada garis besarnya inovasi dalam industri pariwisata ini dikendalikan oleh dua faktor utama. Faktor yang pertama dikategorikan sebagai faktor internal dapat meliputi human capital, kreativitas, keterbukaan (open mindedness), dan kewirausahaan, yang merupakan faktor dominan dalam persaingan bisnis kontemporer. Disamping faktor-faktor internal ini faktor eksternal seperti isuisu global dalam bidang ekonomi, lingkungan, politik, demografi sosial, dan teknologi, juga menjadi faktor makro penentu keberhasilan proses inovasi bagi UKM, disamping faktor mikro seperti selera konsumen, persaingan, dan tekanan pemerintah.

Abernathy \& Clark (1985) mengemukakan empat tipologi inovasi yang dapat diadaptasikan terhadap inovasi pada UKM yang melayani pasar pariwisata. Keempat tipologi ini mencakup: (1) Inovasi penciptaan ceruk baru, (2) Inovasi arsitektural, (3) Inovasi revolusioner, dan (4)
Inovasi reguler.

Inovasi dalam tipologi pertama merupakan inovasi yang mengarahkan perusahaan untuk bergerak kedalam ceruk pasar yang baru. Perusahaan yang mengadopsi tipe inovasi ini menggunakan teknologi dan kompetensi yang telah dimiliki untuk memasuki ceruk pasar yang selama ini belum dilayani oleh perusahaan. Adopsi terhadap tipe inivasi ini umumnya dilakukan pada pasar yang stabil dengan tujuan untuk memaksimalkan pertumbuhan penjualan. Dengan kata lain, inovasi jenis ini sesuai untuk diterapkan oleh perusahaan yang bermaksud untuk melakukan ekspansi pasar denga risiko yang rendah.

Inovasi arsitektural adalah tipologi inovasi yang menggunakan teknologi baru untuk menciptakan ceruk pasar baru. Dengan demikian tipe inovasi ini memiliki risiko yang lebih tinggi dibandingkan dengan inovasi tipe pertama. Perusahaan yang berhasil mengimplementasikan tipe inovasi kedua ini memungkinkan untuk menghasilkan perubahan terhadap industri secara menyeluruh. Hal ini disebabkan karena keberhasilan inovasi pada pasar yang baru dapat berdampak positif terhadap pasar-pasar yang selama ini telah dilayani untuk menerima inovasi sebagaimana ditawarkan kepada ceruk pasar yang baru.

Pada tipe inovasi ketiga, atau inovasi revolusioner, perusahaan memperkenalkan teknologi baru kepada pasar yang selama ini telah dilayani dengan tujuan untuk memelihara eksistensinya pada pasar yang dimaksud. Dengan berfokus pada pasar-pasar yang telah dilayani, perusahaan dapat berhadap untuk menghasilkan dampak perubahan pada sebuah industri dengan tingkat risiko yang tidak terlalu besar.

Tipe inovasi keempat merupakan bentuk inovasi yang mengandalkan teknologi dan atau kompetensi yang telah dimiliki untuk meningkatkan pelayanan yang lebih baik terhadap pasar-pasar yang telah dilayani. Dengan demikian tujuan utama dari tipe inovasi ini adalah meningkatkan kepuasan konsumen, sedemikian akan berdampak pada tingkat pembelanjaan dan loyalitas konsumen terhadap produk-produk yang ditawarkan oleh perusahaan.

\section{Kreativitas Inovasi Produk}

Dalam mendiskusikan kreativitas dalam proses inovasi, akan terdapat setidaknya tiga isu penting yang mencakup isu-su tentang kreativitas individu, kreativitas proses, dan kreativitas ide (Goldenberg \& Mazursky, 2002). Beberapa perusahaan berfokus pada masing-masing isu ini secara terpisah, sementara beberapa perusahaan yang lain mencoba untuk mengintegrasikan 
ketiganya dalam porsi yang berimbang.

Perusahaan yang berfokus pada kreativitas personal akan memelihara dan mempertahankan individu-individu yang mampu membaca dan menciptakan perubahan-perubahan lingkungan dengan cara yang non-mainstream. Seorang yang kreatif adalah ia yang memiliki aliran ide-de besar sepanjang waktu yang dijalaninya. Oleh karena tidak semua ide baru dapat dengan mudah dan segera diterima oleh sebuah masyarakat, maka menjadi tugas entrepreneur, dalam hal ini adalah perusahaan, untuk menahan ide-ide yang dihasilkan ini dan memperkenalkannya kepada masyarakat saat mereka sudah siap dengan inovasi yang ditawarkan.

Kedua, inovasi adalah rangkaian proses kreativitas untuk menciptakan kebaruan atas suatu nilai ekonomi (Marceau, 2011). Berdasarkan pada konsep ini maka yang dimaksud inovasi mencakup tidak hanya penciptaan produ atau layanan baru tetapi mencakup pula proses-proses perubahan organbisasi termasuk didalamnya implementasi metode-metode kerja yang baru untuk tujuan efisiensi dan mendorong kreativitas.

Ketiga, inovasi menyangkut pula isu tentang kreativitas ide. Inovasi harus memunculkan ide-ide bersumber dari kebutuhan atau masalah-msalah yang muncul di masyarakat. Ide yang muncul berbasis masalah yang dihadapi masyarakat ini seringkali muncul sebagai sebuah fenomena yang kompleks dan berkaitan dengan banyak faktor termasuk mungkin di dalamnya adalah persepsi entrepreneur atau ilmuan pencipta inovasi terhadap kebutuhan-kebutuhan ekonomi (Gans, 2011). Hal ini menyangkut pula bagaimana para innovator akan mendapatkan imbal balik atas waktu dan tenaga yang ia curahkan untu memecahkan masalah-masalah yang dihadapi masyarakat dan menemukan solusi inovatif yang bernilai ekonomi.

\section{METODE PENELITIAN}

Penelitian ini difokuskan pada upaya untuk menelaah faktor-faktor apa saja yang menjadi pendorong dan penghambat pengembangan produk pada usaha-usaha kecil penghasil kerajinan seni dan suvenir di Kota Malang untuk melayani pasar wistawan di Bali. Dari survey pendahuluan didapatkan gambaran bahwa inovasi yang dilakukan oleh perusahaan-perusahaan kecil ini sangat bergantung kepada pasar. Dengan kata lain, bisnis yang dijalankan adalah murni market driven. Artinya, usaha-usaha kecil ini hanya berperan sebagai bagian produksi, dengan desain-desain produk yang telah ditetapkan oleh para intermediaries yang menghubungkan produk mereka dengan pasar wisatawan di Pulau Bali (Jaworski et. al, 2000). Selanjutnya didapatkan gambaran bahwa model pengembangan produk dengan berdasarkan desain yang telah diajukan oleh para perantara ini akan menghambat pengembangan sistem bisnis dan pemasaran perusahaan. Disisi lain, model ini membantu perusahaan untuk menjamin kepastian penjualan produknya. Penelitian ini akan melihat secara lebih dekat proses inovasi yang sedang berlangsung di UKM-KM di Kota Malang yang menghasilkan barang kerajinan seni dan suvenir untuk pasar pariwisata di Bali.

Penelitian ini berupaya untuk memberikan gambaran tentang faktor-faktor yang mendorong dan menghambat inovasi dalam program pengembangan produk pada UKM-UKM penghasil produk kerajinan seni dan cenderamata di Kota Malang untuk pasar pariwisata di Pulau Bali. Pendekatan yang akan dilakukan dalam penelitian ini adalah pendekatan kualitatif dengan penggunaan metode yang dijelaskan pada bagian-bagian selanjutnya.

Tahapan awal yang akan dilakukan dalam penelitian ini adalah membangun akses dengan usaha-usaha kecil di Kota Malang yang memproduksi barang kerajinan untuk suvenir wisatawan yang berkunjung ke Pulau Bali (Munck \& Korotayev, 2000). Akses dibangun dengan pendekatan melalui Dinas Perindustrian Kota Malang yang menaungi para pengusaha kecil di Kota Malang dan melalui pendekatan dengan Kadin Kota Malang sebagai wadah bagi pengusaha di Kota Malang untuk menyalurkan segala aspirasinya. Selanjutnya peneliti berkunjung, berinteraksi, dan melihat lebih dekat tentang proses inovasi pada indsutri ini. Dengan telah terbangunnya kedekatan dengan kedua institusi tersebut diharapkan kepercayaan dari pihak UKM sebagai fokus kajian dalam penelitian ini dapat dikembangkan sedemikian interaksi dan komunikasi dengan pihak UKM akan menjadi lebih mudah.

\section{HASIL DAN PEMBAHASAN Pengembangan Produk}

Ide-ide yang kreatif dan menarik perlu untuk dituangkan dalam bentuk yang lebih konkret berupa produk baru. Pengembangan produk baru merupakan aktivitas yang dilaksanakan oleh produsen untuk memperbaiki produk yang telah dihasilkan dengan cara menambah variasi, ragam, atau tingkat mutu produk sesuai dengan keinginan konsumen (Converse, 1986). Opsi yang dapat dipilih oleh perusahaan terkait dengan pengembangan produk ini adalah opsi membuat sendiri atau membeli dari pabrikan lain untuk ditawarkan kepada pasar yang selama ini telah dilayani (Kotler \& Keller, 2012). Kebijakan mengenai produk menjadi pedoman untuk menentukan golongan produk yang akan dibuat atau 
diproses dan sifat-sifat yang bagaimana yang disyaratkan. Kebijakan produk mengikuti perkembangan yang hidup dan selera yang sedang disenangi di masyarakat agar dapat menentukan dan membuat produk yang digemari konsumen secara terus menerus.

Dalam rangka pengembangan produk ini salah satu hal yang penting untuk diperhatikan adalah keputusan untuk membuat atau membeli dan kriteria produsen untuk produk baru. Untuk memproduksi sendiri memerlukan komponen, maka perlu dipikirkan apakah membuat sendiri ataukah membeli komponen tersebut. Untuk mengambil keputusan ini tidaklah mudah. Ada beberapa faktor yang dapat dijadikan sebagai dasar bagi pengambilan keputusan antara lain :

a) Biaya untuk membuat atau membeli komponen

b) Kemampuan khusus untuk mesin-mesin, kemampuan teknik dan luasnya sumber produk yang dibutuhkan .

c) Kemampuan menggunakan kapasitas produksi.

d) Waktu serta kecakapan yang dimiliki oleh manajemen.

e) Kerahasiaan desain, corak, bahan-bahan dan metode proses produksinya.

f) Menarik tidaknya investasi yang diperlukan untuk membuat suatu produk.

g) Kesediaan untuk menanggung resiko pasar.

h) Resiko ketergantungan pada sumber-sumber lain.

i) Besarnya balas jasa yang ada, apakah penyedia juga sebagai langganan perusahaan.

Faktor-faktor ini selanjutnya harus sesuai dengan kriteria produsen untuk produk baru, ada beberapa pedoman yang yang dapat dipakai antara lain :

a) Permintaan pasar harus sesuai

b) Produk tersebut harus disesuaikan dengan faktor-faktor lingkungan dan sosial yang ada. Penekanan faktor lingkungan ini mengarah pada dampak yang akan diakibatkan oleh produk terhadap lingkungan.

c) Produk baru harus sesuai dengan struktur pemasaran yang ada pada perusahaan. Hal ini berarti produk baru harus sesuai dengan pengalaman perusahaan dalam bidang pemasaran yang mencakup wiraniaganya, saluran distribusi dan hal-hal lain yang berkaitan.

d) Produk baru akan lebih menguntungkan jika menggunakan fasilitas produksi, tenaga kerja dan manajemen yang ada.

e) Produk tersebut harus sesuai dengan kemampuan keuangan untuk menghasilkannya.

f) Tidak ada pelanggaran hukum yang dilakukan manajemen, seperti label, merek, paten dan sebagainya. g) Manajemen harus mempunyai waktu dan kemampuan yang memadai untuk menangani pembuatan dan penjualan produk tersebut.

h) Produk tersebut harus sesuai dengan cita-cita dan tujuan perusahaan. (Swastha, 1984).

Dewasa ini kebutuhan-kebutuhan konsumen telah dapat dipenuhi secara cukup di pasar bahkan dapat dikatakan sudah berlebih karena semakin banyaknya produk yang ditawarkan dalam pasar. Keadaan ini menyebabkan pasar bergeser menjadi buyers market. Dengan keadaan yang demikian ini maka salah satu hal yang harus dimiliki oleh perusahaan adalah pengetahuan mengenai perkembangan, keinginan dan kebutuhan konsumen yang selalu berubah-ubah.

Apabila produsen berkeinginan produknya berhasil di pasaran maka ia harus selalu menyesuaikan produk-produknya dengan kebutuhan dan selera konsumen. Dalam hal ini pengembangan terhadap produk-produk yang telah dihasilkan mempunyai peranan yang sangat penting karena pengembangan produk ini akan dapat memenuhi tujuan perusahaan serta dalam rangka mengikuti perkembangan kebutuhan dan selera konsumen yang berubah dan berbeda-beda.

Terdapat setidaknya tiga macam bentuk pengembangan produk yaitu Initial Development, Improvement Development, dan New Use Application (Hermawan, 1983). Bentuk yang pertama mengacu pada usaha untuk memanfaatkan produk-produk untuk penggunaan yang lebih tinggi nilainya, sebagai contoh bambu yang semula dibuat sebagai alat-alat kerajinan dan alat-alat kebutuhan rumah tangga sekarang digunakan sebagai bahan baku pembuat kertas. Improvement development adalah suatu perencanaan produk yang menekankan pada perubahan produk atau perubahan isi dengan tujuan agar mempunyai sifat baru. Dengan perubahan ini diharapkan mempunyai hasil yang lebih menekankan pada keinginan dan kebutuhan konsumen. Kegiatan improvement development ini meliputi kegiatan-kegiatan :

1) Analisis pasar, yaitu memperoleh fakta mengenai kegemaran konsumen dalam hubungannya dengan suatu barang.

2) Analisis objektif, yaitu untuk menentukan manfaat apa saja yang dimiliki suatu barang.

3) Mengubah barang-barang sesuai dengan fakta yang telah dikumpulkan.

Improvement development dijalankan terhadap barang-barang seperti mode pakaian wanita, barang tahan lama seperti televisi dan barang tidak tahan lama seperti makanan dalam kaleng. Bentuk pengembangan produk yang terakhir yakni new use application adalah menggunakan suatu barang yang semula terbatas 
atau tertentu menjadi bermacam-macam barang dengan variasi, karena pembeli dapat memperoleh kegunaan atau manfaat yang lebih banyak daripada sebelumnya. Sebagai contoh adalah plastik yang semula hanya dibuat pembungkus sekarang dapat digunakan sebagai bahan alat-alat dapur, alat bangunan dan sebagainya.

Karena begitu beragam dan banyaknya produk yang dilempar ke pasar, maka terjadilah persaingan antara satu produk dengan produk yang lain guna mendapatkan tempat di pasar dengan mana keadaan ini menyebabkan terjadinya persaingan yang tidak stabil. Disisi lain keinginan, kebutuhan dan daya beli konsumen selalu berubah-ubah. Dengan adanya keadaan yang seperti ini perusahaan yang tidak ingin produknya tersisih di pasar harus selalu memperbaiki produknya untuk menyesuaikan dengan selera dan kebutuhan konsumen dalam hal bentuk, kualitas dan lain sebagainya. Selanjutnya, beberapa faktor berikut perlu dipertimbangkan dalam keputusan pengembangan produk. Pertama, tidak stabilnya kedudukan perusahaan dalam persaingan. Agar perusahaan tidak ketinggalan dari perusahaan lain yang sudah terlebih dahulu mengadakan perbaikan terhadap produknya, maka dengan mengadakan perbaikan terhadap produknya perusahaan akan dapat semakin bersaing bahkan bila perbaikan produknya dapat lebih baik dalam arti lebih dapat memenuhi kebutuhan dan selera konsumen dibandingkan dengan konsep produk yang dihasilkan perusahaan pesaing maka bukan tidak mungkin akan menempati bagian yang lebih besar dalam pasar yang bersaing. Kedua, makin banyaknya variasi penggunaan suatu barang. Makin banyaknya variasi penggunaan suatu barang. Dengan makin banyaknya variasi penggunaan suatu hasil produksi yang mempunyai bermacam-macam penggunaan maka hal ini akan mendorong perusahaan untuk menambah variasi produknya. Misalnya perusahaan kain batik yang semula memproduksi kain batik untuk wanita, sekarang kain batik dapat digunakan untuk pakaian pria, seragam sekolah dan lainnya. Ketiga, pemanfaatan kapasitas produksi. Pada umumnya perusahaan beroperasi tidak pada kapasitas penuh dimana ratarata produksi suatu perusahaan biasanya hanya berkisar antara 75 sampai $85 \%$ saja sehingga sisa kapasitas produksi yang belum terpakai dapat dimanfaatkan. Keempat, munculnya persaingan. Apabila suatu hasil produksi yang ditawarkan oleh suatu perusahaan banyak diminati oleh konsumen dan berhasil di pasar, maka hal ini cenderung untuk menarik perusahaan lain untuk ikut memproduksi produk yang sejenis yang berakibat siklus hidup produk yang bersangkutan menjadi lebih pendek. Untuk mengatasi keadaan yang seperti ini perusahaan harus senantiasa melakukan penyempurnaan terhadap produk yang dihasilkannya atau mencari peluang baru dari produk yang telah dihasilkannya sehingga tidak kehilangan pangsa pasarnya

\section{Program Pengembangan Produk.}

Untuk keberhasilan program pengembangan produk maka sasaran dari kegiatan ini harus ditetapkan dengan jelas. Sasaran pengembangan adalah sasaran pemasaran strategis dan harus menjangkau program pemasaran dalam jangka pendek sehingga memudahkan untuk meramalkan kekuatan pasar yang realistis.

Program pengembangan produk dapat dirancang guna melaksanakan strategi pemasaran untuk suatu produk atau lini produk tertentu. Menurut Guiltinan dan Paul (1994) terdapat empat jenis pokok dari pengembangan produk yang masing-masing dirancang untuk memenuhi sasaransasaran spesifik yang meliputi program modifikasi lini produk, program perluasan lini produk, program produk komplementer, dan program diversifikasi.

Modifikasi lini produk yang telah ada ini mungkin merupakan pendekatan yang paling sederhana. Modifikasi dari produk lama pada umumnya dipilih dengan sasaran meningkatkan penjualan dari lini yang ada saat ini. Jenis program ini mungkin diperlukan untuk mengharapkan strategi pemasaran mempertahankan pelanggan guna memenuhi kebutuhan pembeli yang sedang berubah, untuk mengimbangi penawaran baru dari pesaing, atau sekedar untuk meningkatkan kepuasan terhadap produk. Sasaran ini dapat dicapai dengan merancang ulang atau merumuskan kembali produk untuk menambahkan manfaat baru atau menyempurnakan mutu produk dengan mempergunakan banyak macam kemasan untuk mengurangi peluang pesaing. Perubahan susunan fasilitas yang ada tidak begitu besar, demikian pula dalam hal penggunaan teknologi serta kemungkinan untuk menambah investasi relatif sangat kecil. Modifikasi produk juga dapat meningkatkan penjualan hanya dengan merangsang kebutuhan primer lewat peningkatan angka pembelian. Dengan demikian pendekatan ini dapat dipandang sebagai pendekatan yang mempunyai resiko kecil dan bersifat defensif.

Perluasan lini produk memiliki sasaran untuk menjangkau segmen baru di pasar. Artinya program seperti ini dapat diterapkan untuk menjaring pelanggan pesaing dalam segmen dimana pada saat ini perusahaan tidak mempunyai produk untuk ditawarkan, atau untuk merangsang permintaan diantara bukan para pemakai bentuk produk. Pada situasi tersebut produk yang sama sekali baru harus diciptakan dengan karakteristik produk yang membedakannya dari produk-produk yang ada 
sekarang. Tetapi sampai batas tertentu, perluasan lini produk hampir selalu merupakan substitusi parsial untuk produk lama di lini tersebut karena produk-produk pada lini ini mempunyai fungsi yang sama. Untuk pendekatan terhadap strategi ini perusahaan dapat memanfaatkan salesman yang ada dan metode promosi serta mengaktifkan secara lebih efektif saluran distrbusinya.

Produk-produk komplementer adalah produk yang pada umumnya digunakan bersama-sama dengan produk yang sudah ada. Produk-produk ini dapat dikembangkan baik untuk meningkatkan penjualan produk yang sudah ada ataupun untuk memantapkan pertumbuhan penjualan di pasar yang bersangkutan. Produk komplementer meningkatkan penjualan produk yang sudah ada sampai batas dimana produk tersebut dapat meningkatkan kepuasan atau pemanfaatan dari produk lama.

Diversifikasi adalah suatu kebijaksanaan penambahan produk-produk baru guna melayani pasar yang baru pula. Program diversifikasi pada umumnya dirancang untuk mendirikan perusahaan baru di pasar baru guna mencapai sasaran-sasaran seperti peluang pertumbuhan baru atas stabilitas penjualan. Program diversifikasi ini memerlukan biaya yang mahal karena akan memerlukan saranasarana pendukung yang baru pula seperti fasilitas untuk promosi dan jalur distribusi.

\section{Sumber Ide Pengembangan Produk.}

Proses pengembangan produk baru diawali dengan penggalian gagasan mengenai produk apa yang hendak diluncurkan. Untuk itu terdapat beberapa sumber yang dapat dijadikan sasaran penggalian ide produk baru. Kotler (1995) berpandangan bahwa gagasan mengenai produk baru dapat digali dari berbagai sumber diantaranya pelanggan, ilmuwan, pesaing, agen dan penyalur produk, dan manajemen puncak perusahaan.

Konsep pemasaran secara sederhana mengatakan bahwa keinginan dan kebutuhan konsumen merupakan sumber yang paling masuk akal dalam tahap penggalian gagasan produk baru. Identifikasi atas keinginan dan kebutuhan konsumen ini bisa dijalankan dengan mengadakan penelitian langsung, tes proyeksi, diskusi dengan kelompok tertentu, saran maupun klaim pembeli. Sebagian besar pencari gagasan sampai pada kesimpulan bahwa gagasan-gagasan gemilang lebih sering dijumpai dalam persoalan konsumen yang timbul karena barang yang sedang beredar daripada jika ditanyakan langsung mengenai gagasan produk baru.

Sumber lain dalam proses penggalian ide pengembangan produk baru adalah universitas dan lembaga-lembaga riset. Banyak perusahaan yang mencari gagasan produk baru melalui ilmuwan dengan jalan mengadakan dan memberikan sponsor penelitian dan mencari kemungkinan-kemungkinan perbaikan serta pengembangan pada produk yang sudah ada.

Perusahaan juga bisa memperoleh gagasan produk baru dengan jalan memantau barang-barang pesaing. Informasi tentang produk pesaing ini dapat diperoleh dari para distributor, pemasok dan agen penjualan mereka. Misalnya siapa saja yang membeli produk pesaing dan apa motivasi yang mendorong mereka untuk membeli.

Selanjutnya, agen dan penyalur produk merupakan sumber yang efektif dalam hal gagasan produk baru. Agen dan penyalur produk ini merupakan kelompok pertama yang menampung keluhan-keluhan dan ketidakpuasan dari konsumen. Disamping itu merekalah yang pertama kali mengetahui tentang perkembangan persaingan.

Manajemen puncak mungkin memberi gagasan atas terciptanya produk baru. Misalnya adalah bekas pimpinan perusahaan Polaroid, Edwin $\mathrm{H}$. Land yang memegang tanggung jawab secara pribadi atas inovasi teknologi yang dilakukan di perusahaannya.

\section{Kerajinan Rotan Dalam Konteks Pariwisata}

Indonesia sebagai sebuah negara yang secara geografis terletak di daerah tropis memiliki potensi yang besar untuk mengembangkan hasil pertanian, perikanan, dan kehutanan. Salah satu hasil hutan yang sangat potensial dikembangkan di Indonesia adalah rotan. Dari keseluruhan populasi rotan di dunia, $70 \%$ berada di Indonesia. Disamping sebagai sumberdaya alam yang dapat diperbaharui, rotan dipandang sebagai produk yang ramah lingkungan dan pemanfaatannya tidak berdampak besar terhadap pemanasan global karena sifatnya berbeda dengan hasil hutan lain yang pemanfaatannya dianggap sebagai bentuk deboisasi. Hal ini karena rotan sangat mudah tumbuh di Indonesia dan hanya memerlukan manajemen air yang memadai agar ia tumbuh dengan cepat dan baik.

Saat ini pemerintah Indonesia mencanangkan program hilirisasi industri dimana harus diupayakan seminimal mungkin untuk menjual atau mengekspor komoditi mentah. Dalam hal ini pemerintah berupaya untuk mendorong kreatifitas dunia industri sehingga produk-produk yang dihasilkan Indonesia adalah produk jadi atau setidaknya produk setengah jadi untuk bahan baku. Rotan memiliki potensi yang besar untuk dipasarkan sebagai barang jadi mengingat masyrarakat Indonesia memiliki keterampilan dan pengalaman sejarah yang cukup lama untuk menghasilkan barang-barang kerajinan.

Disamping sumberdaya, pasar merupakan aspek yang tidak kalah penting dalam sebuah bisnis. 
Pasar yang semakin mengglobal memberikan peluang bagi sebuah produk untuk dikonsumsi secara lebih luas. Demikian pula dengan produk kerajinan seperti kerajinan rotan yang dengan berbagai keunggulan dan keunikannya memiliki peluang untuk dipasarkan secara luas di pasar internasional. Salah satu saluran yang dapat digunakan untuk memasarkan produk ini adalah melalui sektor pariwisata.

Pariwisata merupakan sebuah industri dengan kapitalisasi terbesar dibandingkan dengan industri-industri yang lain. Sebagai perbandingan, pendapatan yang dihasilkan pariwisata internasional pada tahun 2007 adalah yang tertinggi diantara industri yang lain yaitu sebesar USD 2.118 miliar, dibandingkan industri otomotif dengan besaran pendapatan senilai USD 1.183 miliar yang pada tahun yang sama menempati posisi kedua. Disamping nilai ekonomi yang besar, industri pariwisata memiliki optimisme untuk tumbuh $4 \%$ sampai dengan tahun 2020. Dengan potensi ekonomi ini, adalah sebuah kewajaran jika banyak negara berupaya mendorong pertumbuhan ekonominya melalui industri pariwisata.

Di Indonesia, Bali menjadi salah satu hub utama bagi pengembangan industri pariwisata. Dengan mengangkat tema Bali sebagai Destinasi wisata budaya, hal ini berimplikasi positif dan menjadikannya sebagai pasar potensial bagi industri kerajinan tidak terkecuali kerajinan rotan. Saat ini Bali telah menjadi pintu utama bagi ekspor kerajinan rotan Indonesia. Pada triwulan pertama tahun 2014 Bali mampu mengekspor kerajinan berbahan baku rotan senilai USD 2,71 juta, sebuah angka yang mengalami peningakatan sebesar tidak kurang dari $700 \%$ dibandingkan periode yang sama tahun 2013 sebesar USD 335 ribu. Jika dahulu produk kerajinan murni dihasilkan oleh perajinperajin Bali, dengan meningkatnya permintaan pasar maka saat ini kebutuhan kerajinan rotan Bali untuk pasar pariwisata diimpor dari daerah-daerah lain di Indonesia terutama Jawa Timur, Jawa Tengah, dan Sulawesi. Dengan demikian, Bali saat ini lebih memiliki kecenderungan sebagai brand bagi produk-produk kerajinan dan seni di pasar pariwisata internasional, sementara fabrikasi dijalankan oleh kawasan lain termasuk Kota Malang yang memiliki reputasi sebagai penghasil kerajinan dan furnitur berbahan baku rotan.

\section{Gambaran Umum Kerajinan Rotan di Kota Malang}

Di era 90-an Kota Malang dikenal luas sebagai pusat kerajinan berbahan baku rotan nasional yang terpusat di Kelurahan Balearjosari. Masyarakat di kawasan ini pada era pemerintahan Belanda telah memproduksi furnitur termasuk anyaman berbahan dasar bamboo. Selanjutnya pada awal tahun 1960an masyarakat perajin bambu mulai beralih ke produksi kerajinan berbahan baku rotan. Perkembangan industri rotan di Balearjosari berkembang pesat pada era 1990an dimana industri ini mampu untuk menyerap sejumlah besar tenaga kerja dan melakukan ekspor secara mandiri ke berbagai negara tujuan terutama negara-negara di Eropa dan Timur Tengah.

Krisis ekonomi tahun 1997 telah berdampak sangat signifikan terhadap perkembangan industri rotan di Balearjosari. Badai krisis telah mengakibatkan banyak usaha kecil penghasil kerajinan rotan gulung tikar bahkan hingga saat ini yang masih dapat bertahan hanya sekitar 23 perusahaan yang terdaftar dalam asosiasi dibawah binaan Pemerintah Kota malang. Selebihnya adalah uasaha kecil rumahan dengan jumlah sekitar 50 usaha. Jumlah ini menurun sangat drastis mengingat pada saat sebelum krisi jumlah perusahaan mencpai lebih dari 300 perusahaan. kemampuan untuk ekspor secara mandiri pada akhirnya juga menurun sangat tajam karena krisis ekonomi telah tidak saja berdampak pada kesulitan keuangan, tetapi juga berdampak pada pergeseran pola permintaan dan selera akan produk-produk rotan yang dihasilkan perajin-perajin di Balearjosari. Bunga bank yang melambung menyebabkan banyak usaha kecil mengalami gagal bayar. Pada gilirannya pemenuhan akan kebutuhan bahan baku untuk produksi kerajinan rotan dan melemahnya daya beli pasar domestik sebagai pasar utama menjadi permasalahan utama dan krusial yang dihadapi oleh indutri kerajinan rotan di Kelurahan Balearjosari.

Pada sisi yang lain, krisis ekonomi yang berdampak luar biasa terhadap penurunan nilai tukar mata uang rupiah, ternyata berdampak positif bagi industri pariwisata nasional terutama di Bali. Sebagai destinasi wisata bereputasi internasional, pelemahan nilai tukar rupiah menjadi peluang bagi wisatawan mancanegara untuk mendapatkan paket wisata ke Bali dengan harga yang lebih murah. Pertumbuhan kunjungan wisatawan yang pesat di Bali telah menjadikannya tidak saja sebagai pasar pariwisata, tetapi menjadi pasar bagi berbagai produk seni dan kerajinan dari seluruh wilayah Indonesia dengan menggunakan Bali sebagai merek. Dengan demikian saat ini Bali muncul sebagai brand bagi produk-produk Indonesia terutama yang berkaitan dengan produk industri seni, kerajinan dan fesyen. Wisatawan yang mengunjungi Bali akan memiliki kebanggaan ketika membeli produk "made in" Bali karena keyakinan wisatawan terutama mancanegara tentang keahlian masyarakat Bali dalam urusan seni dan kerajinan.

Orientasi bisnis pada perusahaan-perusahaan industri rotan di Balearjosari masih sebatas pada 
orientasi produksi, artinya para perajin di daerah ini secara rutin memproduksi kerajinan rotan berdasarkan pada pesanan dan jika terdapat kelebihan produksi akan dipajang di "showroom" dalam rangka untuk dijual kepada calon pembeli yang berkunjung ke toko-toko para perajin tersebut. Disamping toko yang dimiliki oleh perajin, terdapat juga showroom yang dimiliki oleh pedagang perantara. Dengan demikian, maka yang menjadi sasaran dari bisnis yang dijalankan adalah melakukan efisiensi produksi dengan tujuan untuk meningkatkan laba.

Dengan orientasi seperti ini maka yang dapat dilakukan oleh perajin rotan adalah melakukan inovasi-inovasi pada proses produksi yang sebagian besar terbatas pada efisiensi terhadap bahan baku dan tenaga kerja, meskipun pada beberapa tahapan mereka telah menggunakan teknologi masinal dan elektrikal. Keterbatasan pada inovasi produksi seperti ini (Berghman et. al, 2006) pada gilirannya akan berdampak pada sulitnya sebuah bisnis untuk berkembang. Secara rasional, seorang pengusaha tidak akan meningkatkan kapasitas produksinya jika tidak ada perluasan atau peningkatan daya serap pasar. Dalam konteks ini, efisiensi produksi yang dapat dicapai hanya akan meningkatkan laba prusahaan tetapi tidak mampu untuk meningkatkan penjualan. Dengan demikian, secara operasional inovasi produksi yang dapat dilakukan oleh produsen kerajinan rotan ini adalah (1) efisensi secara teknis, yaitu faktor-faktor produksi yang dimiliki diupayakn seoptimal mungkin untuk menghasilkan output yang maksimal, dan (2) efisiensi alokatif melalui penyesuaian harga terhadap biaya produksi marjinal.

\section{Inovasi dan Pengembangan Produk Kerajinan}

Sebelum strategi dalam pengembangan produk ditentukan, perlu untuk terlebih dahulu menelaah karakterikstik produk yang dihasilkan. Produk kerajinan merupakan kategori produk manufaktur yang memiliki sifat tahan lama secara fisik dengan intensitas pemakaian yang banyak dan berulang. Namun demikian, produk-produk kerajinan termasuk kerajinan rotan juga sangat dipengaruhi oleh tren atau fesyen sedemikian desain untuk produk-produk seperti ini memungkinkan untuk memiliki perputaran yang tinggi. Artinya, sebuah desain produk kerajinan mungkin akan segera menjadi usang manakala model atau permintaan berdasarkan fesyen terbaru muncul.

Dengan melihat pada karakteristik produk kerajinan rotan ini maka strategi pengembangan produk dapat dilakukan melalui dua strategi. Pertama, pengembangan produk kerajinan rotan dapat dilakukan dengan cara memperbaiki produk sehubungan dengan adanya fakta tentang faktor konsumen yang dinamis. Konsumen produk kerajinan adalah konsumen yang dinamis dan mengikuti tren fesyen desain dan arsitektur (cf. Moutinho, Ballantyne, \& Rate, 2011). Sebagai contoh, produk-produk furniture rotan saat ini harus lebih banyak diproduksi dengan desain minimalis karena tren arsitektur perumahan saat ini condong ke gaya minimalis. Kedua, pengembangan produk kerajinan rotan dapat pula dilakukan dengan mengubah ragam produk yang ada dengan cara menambah atau membuat produk yang berbeda dengan produk-produk yang saat ini telah diproduksi oleh perusahaan. Masalah yang muncul dalam konteks industri kerajinan rotan di sentra kerajinan Balearjosari adalah sebagian besar produkyang dibuat adalah produk-produk berdasarkan pesanan. Dengan demikian yang dapat dilakukan oleh para perajin adalah menjadikan desain-desain pesanan sebagai model bagi konsumen yang lain.

Dalam rangka mengambil keputusan mengenai strategi pengembangan produk seperti apa yang seharusnya diambil oleh perajin rotan, maka beberapa pertimbangan berikut menjadi krusial. Pertimbangan pertama adalah biaya untuk membuat atau membeli produk atau komponen untuk pengembangan produk. Produk-produk baru yang sesuai dengan permintaan atau selera pasar belum tentu sama dengan sumberdaya yang dimiliki oleh perusahaan. Oleh karena itu perusahaan harus jeli untuk menelaah, apakah harus memproduksi sendiri atau harus melakukan outsource dalam rangka untuk memenuhi keinginan pasar yang dinamis tersebut. Kedua, pertimbangan mengenai kemampuan untuk menggunakan kapasitas produksi. Ketiga, waktu dan kecakapan manajemen dalam menangani pengembangan produk baru untuk memenuhi kebutuhan dan keinginan pasar, dalam hal ini termasuk bagaimana pengelolaan terhadap kemampuan sumberdaya keuangan. Keempat adalah pertimbangan yang terkait dengan kerahasiaan desain, bahan, dan proses produksinya. Produk kerajinan rotan adalah produk tangible yang akan dengan mudah ditiru oleh pesaing. Dengan demikian perlu dipertimbangkan seberapa lama kemampuan pesaing untuk kemudian menduplikasi produk baru yang dihasilkan oleh perusahaan. Pertimbangan kelima adalah menyangkut kesediaan untuk menanggung risiko atas kegagalan produk di pasar.

\section{Sumber Ide Pengembangan Produk Kerajinan}

Berdasarkan pada pengamatan yang dilakukan di sentra kerajinan rotan Balearjosari, produk yang dihasilkan oleh masing-masing unit usaha kerajinan rotan relatif memiliki desain yang sama anatar satu perajin ke perajin lainnya. Hal ini menunjukkan 
bahwa pemesan atau pembeli produk yang melayani pasar tertentu berupaya untuk menyebar pesanannya dengan tujuan untuk efisiensi waktu dan biaya. Produk-produk pesanan seperti ini umunya akan dijual tanpa menggunakan merek, dimana pemesan akan akan memberikan merek tersendiri yang lebih marketable di pasar sasaran yang dibidiknya. Strategi seperti ini banyak dilakukan oleh pengusaha ekspor atau pedagang kerajinan rotan dari Bali. Para perrantara ini mendapatkan pasokan dari perajin dengan harga pasaran lokal untuk kemudian dijual dengan harga yang berlipat di pasar pariwisata dengan menggunakan nama "Bali" sebagai merek dagang. Dengan demikian sumber ide pengembangan produk yang berkaitan dengan desain didominasi oleh para perantara yang mengetahui secara persis kebutuhan dan keinginan pasar akan produk-produk kerajinan dan furniture berbahan baku rotan.

Sementara itu, desain yang disediakan oleh perajin adalah desain yang sudah dikerjakan secara turun temurun dan kebanyakan untuk melayani pasar lokal. Keahlian untuk menganyam rotan dapat dikatakan telah menjadi bagian dari budaya setempat karena telah dilihat, dipelajari, dan dipraktikkan sejak masa kecil dengan bimbingan orang tua secara turun-temurun. Pada gilirannya, perajin-perajin muda akan memiliki kecenderungan untuk mempertahankan desain-desain yang telah mereka pelajari secara turun-temurun sebagai bentuk apresiasi terhadap pelastarian budaya. Dalam kondisi seperti ini maka ide pengembangan produk yang bersumber dari perajin lokal adalah ide-ide tentang perbaikan produk melalui upayaupaya kreatif untuk efisiensi dan teknik-teknik yang lebih mutakhir untuk memproduksi dengan biaya yang lebih murah.

Dengan inovasi untuk pengembangan produk yang dilakukan dengan pola ini, diyakini bahwa meskipun saat ini usaha kerajinan dan furnitur rotan di Balearjosari belum bangkit kembali sebagaimana kejayaan di era 90an, namun bisnis rotan di kawasan ini akan terus hidup dan berkembang kembali setahap-demi setahap. Dua hal utama yang menjadikan kondisi ini akan berlangsung adalah, pertama, para pembeli, terutama perantara dari Bali yang menjual produk rotan ke pasar ekspor, telah meyakini keahlian masyarakat Balearjosari dalam hal kreativitasnya mengolah produk-produk rotan dengan efisien. Yang kedua adalah semangat masyarakat untuk mewarisi dan melestarikan industri anyaman rotan sebagai bagian dari sistem budaya dan mata pencaharian mereka, disamping optimisme bahwa industri ini akan mampu untuk berkembang dan menjadi modal bagi keberlangsungan budaya yang sudah dibentuk.

\section{Proses Pengembangan Produk}

Proses pngembangan produk di sentra kerajinan anyaman rotan Balearjosari dapat dibedakan menjadi dua proses utama. Proses yang pertama adalah pengembangan produk dilakukan oleh perajin yang memang memiliki keahlian untuk membuat anyaman rotan. Secara terus menerus melalui rutinitas pekerjaan yang digelutinya seorang perajin belajar untuk menciptakan produkproduk yang lebih baik baik dari segi kualitas maupun harga yang bersaing. Proses yang kedua dapat melalui orang yang tidak memiliki keahlian secara teknis dalam kerajinan anyaman rotan, namun memiliki ide-ide kreatif tentang bagaimana menjadikan kerajinan rotan ini menjadi lebih berkualitas, lebih murah, dan berdaya saing. Yang disebut kedua biasanya adalah entrepreneur pendatang-pendatang baru di industri kerajinan anyaman rotan yang memiliki ide-ide untuk melayani pasar dengan cara yang lebih baik. Kelompok kedua ini umumnya lebih fleksibel dan lebih dinamis dalam mengembangkan proses pengembangan produk.

Menarik untuk dicermati dalam kasus ini adalah kebanyakan pengusaha dalam kelompok kedua lebih berhasil dalam mengembangkan bisnis mereka meskipun mereka tidak memiliki keahlian menganyam rota (cf. Fyall \& Garrod, 2005). Dalam hal ini peneliti berteori bahwa kunci keberhasilan dalam mengembangkan bisnis kerajinan dan furnitur rotan di kawasan Balearjosari bukan terletak pada keahlian untuk menganyam dan keahlian untuk berinovasi membuat proses produksi menjadi lebih efisien, namun kreativitas dalam penciptaan ide akan desain-desain yang diminati pasar merupakan kunci utama dalam mengembangkan bisnis kerajinan rotan (Bieger \& Weinert, 2006). Dengan demikian pemahaman terhadap riset pasar saja tidak cukup, tetapi perlu memiliki keahlian dalam riset pemasaran untuk mencapai kreatyivitas ini. Pada contoh kasus di sentra kerajinan rotan Balearjosari, keahlian riset pemasar tidak diperoleh secara khusus melalui pendidikan pemasaran, tetapi diperoleh secara natural melalui kecermatan membaca peluang pasar, kemampuan untuk mencari informasi tren desain dan arsitektural, serta kemauan yang tinggi untuk berinovasi dan mengembangkan produk dengan menanggung segala risiko kegagalannya. Seringkali apabila para pengusaha ini berhasil menembus pasar dengan menjual desain dari idenya sendiri, maka ia akan lebih mudah untuk mengikuti perkembangan pasar dan menciptakan desiandesain baru secara lebih cepat sedemikian ia menjadi first mover dalam industri.

Proses pengembangan produk dengan menggunakan ide sendiri pada gilirannya mampu 
untuk menciptakan inovasi proses produksi (Barras, 1986). Sebagaimana yang terjadi pada salah satu pengusaha kerajinan rotan di Balearjosari yang tidak memiliki keterampilan menganyam rotan ini, bapak $\mathrm{X}$, ia mengkombinasikan desain anyaman rotan dengan produk-produk murah non rotan seperti eceng gondok atau mendong untuk menyiasati berkurangnya pasokan rotan. Disamping itu penggunaan bahan sintetis juga diaplikasikan dalam kadar tertentu mengingat harga rotan sintetis yang lebih mahal tetapi tersedia dalam jumlah yang lebih banyak untuk saat ini. Dengan demikian, maka bagi konsumen desain adalah lebih penting daripada orisinalitas bahan baku, yaitu rotan.

\section{Penetapan Kebijakan Pengembangan Produk}

Berdasarkan pada analisis melalui proses observasi lapangan dapat ditarik beberapa poin terkait dengan penetapan kebijakan perusahaan dalam rangka pelaksanaan program pengembangan produk kerajinan rotan di Balearjosari untuk meningkatkan volume penjualan sebagai berikut.

1. Melaksanakan Manajemen Produk. Melaksanakan manajemen terhadap produk secara efektif terutama terhadap produk-produk lama mengingat produk-produk lama yang telah dihasilkan selalu mengalami penurunan penjualan. Dengan demikian maka siklus hidup produk menjadi lebih lama dan sumbangan terhadap naiknya volume penjualan tidak hanya diperoleh dari peluncuran produk baru saja mengingat besarnya biaya pengembangan produk.

2. Melakukan penekanan biaya produksi. Dengan penekanan biaya produksi maka harga pokok penjualan akan lebih rendah sehingga memungkinkan perusahaan untuk dapat lebih bersaing dengan perusahaan pesaing dari kawasan lain.

3. Melakukan kebijaksanaan penjualan yang lunak. Dalam hal ini adalah memberikan jangka waktu pembayaran atas pembelian kredit kepada perantara untuk tujuan ekspor di pasar wisata dalam jangka waktu yang lebih lama terutama untuk produk-produk baru sehingga perantara memiliki keleluasaan waktu untuk memasarkan produk.

4. Melakukan promosi yang lebih efektif. Kegiatan promosi yang lebih efektif terutama dapat dilakukan melalui berbagai media terutama internet yang selama ini jarang dilaksanakan oleh perusahaan-perusahaan di sentra industri rotan Balearjosari. Dengan kegiatan promosi melalui media internet ini diharapkan produk akan dikenal secara lebih luas oleh konsumen, terutama promosi untuk produk-produk baru harus lebih gencar mengingat produk yang baru diluncurkan seringkali kurang cepat dikenal oleh masyarakat atau konsumen secara meluas.

5. Memperluas daerah pemasaran. Dengan memperluas daerah pemasaran, maka ada kemungkinan konsumen yang tadinya belum mengenal hasil produksi perusahaan, akan mengkonsumsi produk perusahaan. Cara yang dapat diterapkan dalam rangka memperluas daerah pemasaran ini adalah dengan mengembangkan saluran distribusi di kawasankawasan wisata utama selain Bali seperti Yogyakarta, Batam, Jakarta, dan destinasi wisata lain yang sedang berkembang. Dengan perluasan saluran distribusi strategi repositioning untuk produk-produk lama dapat diterapkan.

6. Menetapkan positioning produk secara lebih jelas dengan mempertimbangkan otentisitas hasil produksi (cf. Ooi \& Stöber, 2010)

Dalam hal ini segmen pasar perusahaan sudah ditetapkan. Namun demikian masih perlu untuk melaksanakan positioning untuk masingmasing produk sehingga pasar sasaran menjadi semakin jelas untuk tiap-tiap jenis kerajinan yang diproduksi.

\section{KESIMPULAN DAN SARAN \\ Kesimpulan}

Berdasarkan pada hasil penelitian yang telah dilakukan dapat ditarik kesimpulan-kesimpulan sebagai berikut:

1. Inovasi dalam proses pengembangan produk kerajinan di sentra kerajinan rotan Balearjosari dapat bersumber dari tiga pemeran utama industri, yaitu (1) perajin yang memiliki ketrampilan menganyam dan sevara turun temurun menjalani proses belajar anyaman rotan, (2) entrepreneur kerajinan rotan yang memiliki kreativitas dalam hal desain produkproduk kerajinan dan furnitur rotan, dan (3) para perantara yang menjual ke pasar-pasar tertentu seperti pasar pariwisata yang mengetahui secara persis kebutuhan dan keinginan pasar.

2. Industri kerajinan rotan di sentra kerajinan rotan Balearjosari diyakini akan terus bertahan dan akan berkembang seiring dengan kepercayaan konsumen akan kualitas produk yang dihasilkan oleh perajin di sentra industri ini. Pada sisi yang lain, para perajin memiliki motivasi yang tinggi untuk mempertahankan budaya menganyam rotan karena aktivitas ini dapat memberikan penghasilan yang cukup bagi masyarakat Kelurahan Balearjosari.

3. Keberhasilan dalam mengembangkan bisnis kerajinan rotan lebih dimungkinkan melalui 
kreativitas dalam penciptaan desain-desain baru daripada melaui inovasi produksi untuk menghasilkan produk yang lebih efisien

\section{Saran}

Rekomendasi praktis yang dapat diajukan melalui pelaksanaan penelitian ini antara lain adalah:

1. Perlunya untuk meningkatkan kemampuan perajin atas kreativitas desain melalui pelatihan-pelatihan baik teknikal maupun manajerial.

2. Promosi secara lebih gencar perlu dilakukan dengan menekankan upaya promosi sebagai bentuk investasi, bukan sebagai biaya.

3. Perluasan pasar perlu untuk dilakukan mengingat pada masa yang lalu produk berbahan baku rotan dari sentra kerajinan rotan Balearjosari telah dikenal luas baik di pasar domestik maupun mancanegara.

\section{Implikasi Bagi Penelitian Selanjutnya}

Penelitian ini dilakukan dalam bentuk studi kasus terhadap perilaku produsen penghasil produk kerajinan dan furnitur rotan. Dengan demikian penelitian ini memiliki keterbatasan dalam hal melihat perilaku pasar dalam menerima produk kerajinan rotan. Penelitian selanjutnya disarankan untuk dilakukan dengan melihat perilaku konsumen dan pedagang perantara di pasar parisata sedemikian gambaran perilaku pelaku bisnis kerajinan rotan dapat digambarkan secara komprehensif.

\section{DAFTAR PUSTAKA}

Abernathy, W. J., \& Clark, K. B. (1985). Innovation: Mapping the Winds of Creative Destruction. Research Policy, 14, 3-22.

Alwasilah, A. C. (2002). Pokoknya Kualitatif: Dasar-Dasar Merancang dan Melakukan Penelitian Kualitatif. Jakarta: Dunia Pustaka Jaya.

Barras, R. (1986). Towards a theory of innovation in services. Research Policy, 15(4), 161-173.

Berghman, L., Matthysens, P., \& Vandenbemt, K. (2006). Building Competence for New Value Creation: An Exploratory Study. Industrial Marketing Management, 35, 961-973.

Bieger, T., \& Weinert, R. (2006). On the Nature of the Innovative Organization in Tourism: Structure, Process and Results. In B. Walder, K. Weiermair \& A. S. Perez (Eds.), Innovation and Product Development in Tourism: Creating Sustainable Competitive Advantage (pp. 88-102). Berlin: Erich Schmidt Verlag
Converse, P. D, et al. (1986). Elements of Marketing. Disadur oleh A. Suljus Notorahardjo. Unsur-Unsur Marketing. Bandung: Alumni.

Fyall, A., \& Garrod, B. (2005). From Competition to Collaboration in the Tourism Industry. In W. F. Theobald (Ed.), Global Tourism (Third ed., pp. 52-73). Amsterdam: Elsevier.

Gallouj, F., \& Windrum, P. (2009). Services and services innovation. Journal of Evolutionary Economics, 19(2), 141-148.

Gans, J. (2011). Economic Approaches to Understanding

and Promoting Innovation. In L. Mann \& J. Chan (Eds.), Creativity and Innovation in Business and Beyond (pp. 82-102). New York: Routledge.

Guiltinan, P. J. \& Paul, G. W. (1994). Strategi dan Program Manajemen Pemasaran. Edisi Kedua, Cetakan Keempat. Alih Bahasa : Agus Maulana. Jakarta : Erlangga

Goldenberg, J. \& Mazursky, D. (2002). Creativity in Product Innovation. New York: Cambridge University Press.

Hermawan, Atang. (1983). Tanya Jawab Marketing. Edisi Pertama. Bandung : Armico.

Jaworski, B. J., Kohli, A. K., Sahay, A. (2000). Market-Driven Versus Driving Markets. Journal of the Academy of Marketing Science, 28(1), 45-54.

Kotler, P. \& Keller, K. L. (2012). Marketing Management. Boston: Pearson.

Kotler, P. (1995). Manajemen Pemasaran. Analisis, Perencanaan, Implementasi dan Pengendalian. Jilid 1. Edisi Kelima. Alih Bahasa : Jaka Wasana. Jakarta : Erlangga.

Marceau, J. (2011). Innovation and Creativity in Industry and the Service Sectors. In L. Mann \& J. Chan (Eds.), Creativity and Innovation in Business and Beyond (pp. 32-49). New York: Routledge.

Moutinho, L., Ballantyne, R., \& Rate, S. (2011). The New Business Environment and Trends in Tourism. In L. Moutinho (Ed.), Strategic Management in Tourism (2nd ed., pp. 1-19). Wallingford: CABI.

Munck, V. d., \& Korotayev, A. (2000). Cultural Units in Cross-Cultural Research. Ethnology, 39(4), 335-348. 
Ooi, C.-S., \& Stöber, B. (2010). Authenticity and Place Branding: The Arts and Culture in Branding Berlin and Singapore. In B. T. Knudsen \& A. M. Waade (Eds.), ReInvesting Authenticity: Tourism, Place and Emotions (pp. 66-79). Bristol: Channel View

\section{Publications.}

Swastha, D. H. B. (1984). Manajemen Barang Dalam Pemasaran. Edisi Kedua, Cetakan Pertama. Yogyakarta : BPFE. 